\title{
OPTIMIZATION OF ARTIFICIAL NEURAL NETWORKS USING ANT COLONY OPTIMIZATION TO IDENTIFY SIGNATURE IMAGES
}

\author{
Junia Kurniati ${ }^{* 1}$, Reza Firsandaya Malik ${ }^{*} 2$ \\ Program Studi Ilmu Komputer Program Magister, Fakultas Ilmu Komputer, \\ Universitas Sriwijaya, Palembang, Indonesia \\ ${ }^{*}$ Email : niyaazulkarnain@gmail.com ${ }^{1}$,reza.firsandaya@gmail.com ${ }^{2}$
}

\begin{abstract}
Biometrics can be used in identification and recognition systems because it is a method for recognizing human based on one or more unique behaviors or physical features, one of which is the signature. In its application, signatures need to be examined because signatures are often imitated or falsified for various purposes. In this paper, signatures were identified by performing the feature extraction process using the Gabor Wavelet Transform (GWT) method. After extracting, the signature identification process is carried out using the Neural Network. In the process of applying the Neural Network method, optimization was performed using Ant Colony Optimization. The results show that the identification of signatures made using the Neural Network alone produced an accuracy of $77 \%$, but after optimization using Ant Colony Optimization increased to $83 \%$.
\end{abstract}

Keywords: Signature, Identification, Neural Network, Ant Colony Optimization

\begin{abstract}
Abstrak
Biometrika dapat digunakan pada sistem identifikasi atau pengenalan karena merupakan metode untuk pengenalan manusia berdasarkan pada satu atau lebih tingah laku yang unik atau ciri-ciri fisik, salah satunya adalah Tanda Tangan. Pada penerapannya, tanda tangan perlu dilakukan pemeriksaan (identifikasi) karena tanda tangan sering kali di tiru atau dipalsukan untuk berbagai macam kepentingan. Tanda tangan yang akan di identifikasi akan diambil terlebih dahulu ciricirinya dengan melakukan proses ekstraksi ciri menggunakan metode Transformasi Gabor Wavelet (TGW). Setelah diekstraksi lalu dilakukan proses identifikasi tanda tangan menggunakan Neural Network. Pada proses identifikasi, pada metode Neural Network akan dilakukan optimalisasi menggunakan Ant Colony Optimization. Hasil penelitian memperlihatkan bahwa identifikasi tanda tangan yang dilakukan menggunakan Neural Network saja menghasilkan akurasi sebesar 77\%, namun setelah dilakukan optimalisasi menggunakan Ant Colony Optimization meningkat menjadi $83 \%$.
\end{abstract}

Kata Kunci: Tanda Tangan, Identifikasi, Neural Network, Ant Colony Optimization

\section{Introduction}

The use of signatures as a reference for data validation in its application takes a long time. Unfortunately, errors often occur in the identification process caused by manual checking system, thus a system that is able to accelerate the data validation process using digital image identification technology is needed. Some pattern recognition and extraction methods to obtain specific information in displaying the signature image characteristics have been proposed. For example, the development of identification of signatures was proposed using Support Vector Machines [1], Elliptic Curve [2] or Backpropagation neural network [3]. In addition, the Gabor Wavelet Transform extraction method for the feature extraction process has been carried out in several studies, including face recognition in presence systems using dynamic times wrapping methods, principal component analysis, and Gabor wavelets by Wiryadinata, et al with accuracy $69.33 \%$ [4]. After the Gabor Wavelet Transform feature extraction is performed, the Ant Colony Optimization method [5, 6, 7, 8] is used on the Neural Network as a method to optimize the signature image identification process. The Neural Networks have also been carried out in several studies, including the implementation of backpropagation Neural Networks in weather forecasts in the area of southern Bali with an accuracy of $51.61 \%$ [9]. In addition, Ant Colony Optimization as new feature selection algorithm based on binary Ant Colony Optimization has been conducted by Kashef et al with accuracy $86 \%$ [10]. Based on the accuracy achieved by each method in several previous studies and their uses, this paper reported the development of software using Gabor Wavelet Transform, Neural Network, and Ant Colony Optimization to identify the signature image. 


\section{Methodology}

\subsection{Stages of Methodology}

Overall the methodological steps can be illustrated in the flow chart in Figure 1. It shows the path diagram of the methodology used. The method in this research was developed using Gabor Wavelet Transformation, Neural Network, and Ant Colony Optimization, as well as data collection techniques in the form of primary data for processing signature images. The research stage is presented in the form of a process diagram with input in the form of input data, namely the initial stages consisting of input data queries for the training process (enrollment) and input data testing for the identification process. The next stage is data processing enrollment that will process the extraction of image data using the Gabor Wavelet Transform, then stored in a database. Data in the database will be used in the pattern recognition process using Neural Network and optimized using Ant Colony Optimization. In the identification process, feature extraction and pattern recognition are also performed which is tested for compatibility against the data that has been trained. In this research the Windows 7 64bit operating system environment was used, with hardware specifications using Intel Core I-5 and memory with a capacity of $10 \mathrm{~GB}$, and a 500GB hard drive. The test results on the system is displayed in the form of images of the extraction of features, values and level of accuracy as well as the results of pattern recognition in visual and graphic form.
The steps taken in this research are:

1. Converting concepts: Namely the Gabor Wavelet Transform test method used as feature extraction, Neural Network as pattern recognition and Ant Colony Optimization to optimize the Neural Network method.

2. Analyze signature image objects: Knowing the characteristics of signature image patterns as data objects used.

3. Describe the Gabor Wavelet Transformation architecture, Neural Network and Ant Colony Optimization: Create architectures and flowchart diagrams that describe the workings of the method used in outline to identify the image of the signature.

4. Collect signature image sample data: Collect and process primary image signature data that are used as research objects.

5. Preprocessing: This is the stage for preparing data that has been obtained from the data collection stage and processing it before it is used at a later stage.

6. Developing software: Developing software according to the method used to carry out the process of learning and testing data.

7. Experimentation and Testing: This stage will carry out the process of experimentation and testing of data using software that has been developed.

8. Evaluation and Analysis: This stage will discuss the results of evaluations from experiments that have been carried out, display and analyze the results obtained from the research along with an explanation.

9. Make conclusions and suggestions: Make conclusions and suggestions from the results of the analysis that has been made for further research purposes.

Back Propagation Neural Network

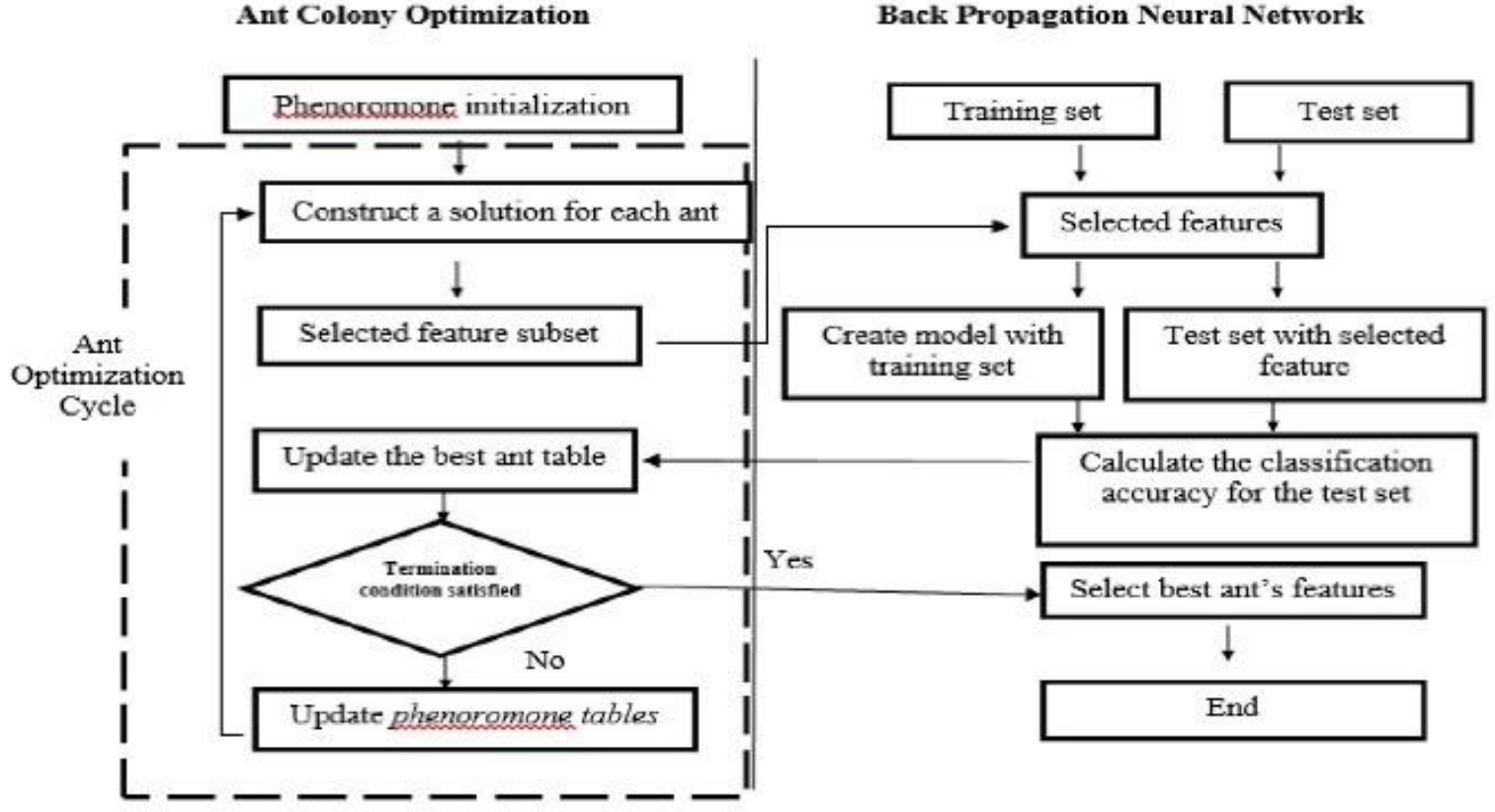

Figure 1. Flowchart of Neural Network and Ant Colony Optimization 


\subsection{Signature Characteristics}

Signatures have the same shape on everyone but can also vary based on circumstances or several factors, some of which are caused by changes such as a person's character, emotions and mood conditions, and the environment. To identify someone's signature, it requires a lot of variations in the person's signature because for the same person it will produce a different signature, meaning that the signature will change based on position, size, slope, obscurity and so forth. This change makes signatures more difficult to identify. In addition to differences in someone's signature, another characteristic of a signature is the difference in the signature of another person who will be processed so that the identification of ownership of the respective signature will be known to the amount of data based on the signature of some of these people [9]. This is some examples of someone's signature in Figure 2.

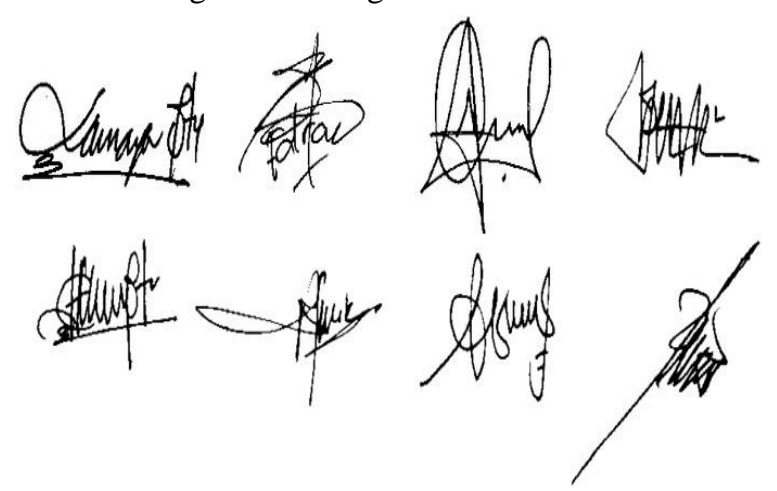

Figure 2. Signature Images

\subsection{Feature Extraction}

In this research the Gabor Wavelet Transform method is used as a method to extract the features of the image to be processed so that the extraction value will be obtained. The stages of the Gabor Wavelet Transformation process area as follows [11],[12]:

\section{Gabor Wavelet Value}

How to obtain a 2D Gabor Wavelet value based on the orientation angle and the scaling transformation of the Gabor Wavelet texture $\Psi(x, y)$ with the equation:

$$
\begin{gathered}
\Psi(x, y)=a^{-1} \Psi\left[a^{-1}(x \sin \theta+\right. \\
\left.y \cos \theta), a^{-1}(x \cos \theta-y \sin \theta)\right]
\end{gathered}
$$

where :

$x, y:$ coordinate position to be built from the wavelet value

$a$ : transformation based on scaling illustrated by a scale factor

$\theta \quad: \quad$ the magnitude of the orientation angle used is set by the parameter

2. Gabor Wavelet Kernel

The formula used to form each Gabor kernel is:
$\Psi\left(x^{\prime}, y^{\prime}\right)=\exp \left[-\frac{1}{2}\left\{\frac{x^{\prime 2}}{\delta_{x}^{2}}+\frac{y^{2}}{\delta_{y}^{2}}\right\}\right] \cos \left(2 \pi f x^{\prime}\right)$

Where :

- $x^{\prime}, y^{\prime}$ : coordinate position of the wavelet value that has been built

- $\delta_{x}, \delta_{n}$ : constant value as the standard value of the gaussian envelope deviation

- $\quad f$ : sinusoidal frequency which shows the amount of alternating motion that occurs in an image

- $\pi$ : the ratio constant to the diameter of the geometry circle

3. Convolutional Gabor Wavelet Transformation

This formula the equations used in the Gabor Wavelet Transform convolutional process:

$G_{l, k}(x, y)=I(x, y) * \Psi_{l, k}(x, y)$

$l=1,2, \ldots, 4$ and $k=1,2, \ldots, 6$

Where:

$I(x, y) \quad$ : input image of $\mathrm{x}, \mathrm{y}$ coordinates

$\Psi_{l, k}(x, y)$ : $\quad$ kernel of Gabor Wavelet Transform

$l \quad: \quad$ angle orientation value

$k \quad: \quad$ sequential scale values

4.Feature Extraction

The Gabor Wavelet Transform feature can be obtained using the mean and standard deviation which are formulated as follows:

$\mu(x, y)=\frac{1}{M N} \sum_{m=1}^{M} \sum_{n=1}^{N}\left|G_{l, k}(x, y)\right|$

$\sigma=\sqrt{\frac{1}{M N} \sum_{m=1}^{M} \sum_{n=1}^{N}\left(\left|G_{l, k}(x, y)\right|-\mu_{l, k}\right)^{2}}$

Where:

$G_{l, k}(x, y)$ : image output of Gabor Wavelet Transform

$\mu(x, y)$ : the average output value of the Gabor Wavelet Transform image

$\sigma \quad: \quad$ average standard deviation

$M \quad$ : amount of data $m$

$N \quad$ : amount of data $n$

\subsection{Pattern Recognition}

The pattern recognition used in this research is the Neural Network method. Artificial Neural Network is a paradigm of processing information that is inspired by the biological nerve cell system, just like the brain that processes information. The basic element of the paradigm is the new structure of the information processing system. Neural Networks, like humans, learn from an example. Artificial Neural Networks are formed to solve a particular problem such as pattern recognition or classification because of the learning process. The architecture used in this research is Backpropagation feedforward with the layer used is multilayer. Backpropagation is used by perceptron to change weights with multiple layers connected to neurons in the hidden layer and is a supervised learning algorithm. Error output is used in the backpropagation algorithm to change the weight value in the backward direction. The forward propagation stage must be done first to get an 
error. At the time of forward propagation the sigmoid activation function is used to activate neurons using [13]:

$$
f(x)=\frac{1}{1+e^{-x}}
$$

\section{Backpropagation Algorithm:}

1. Initialization of weights and bias. Both the bias and the weight can be set with random or random numbers and usually numbers and numbers 0 and 1 or -1 (negative or positive bias).

2. Take the following steps for the stop condition is FALSE:

(i). For each pair of elements that will be train, do it:

Feedforward:

a. Signal $\mathrm{X}_{\mathrm{i}}$ received by each input unit $\left(\mathrm{X}_{\mathrm{i}}, \mathrm{i}=\right.$ $1,2,3, \ldots, n)$ and the signal is transmitted to all units in the hidden layer (the layer above it).

b. The weighted input signals are summed with each hidden unit $\left(\mathrm{Z}_{\mathrm{i}}, \mathrm{j}=1,2,3, \ldots, \mathrm{p}\right)$, that is:

$$
z_{-} i n_{j}=v_{0 j}+\sum_{i=1}^{n} x_{i} v_{i j}
$$

The activation function is used to calculate the output signal to use:

$$
z_{j}=f\left(z \_i n_{j}\right)
$$

and the signal is sent to all units (output units) in the upper layer.

c. The weighted input signals are summed with each unit of output $\left(\mathrm{Y}_{\mathrm{k}}, \mathrm{k}=1,2,3, \ldots, \mathrm{m}\right)$ with:

$$
y_{-} i n_{k}=w_{0 k}+\sum_{i=1}^{p} z_{i} w_{j k}
$$

The activation function is used for the calculation of the output signal using: $\mathrm{y}_{\mathrm{k}}=\mathrm{f}\left(\mathrm{y} \_\mathrm{in}_{\mathrm{k}}\right)$ (10)

These signals are sent to all units in the layer above it (output units).

Backpropagation

d. Calculate the error information for each unit of output $\left(\mathrm{Y}_{\mathrm{k}}, \mathrm{k}=1,2,3, \ldots, \mathrm{m}\right)$ related to learning input patterns that accept target pattern uses:

$$
\delta_{\mathrm{k}}=\left(\mathrm{t}_{\mathrm{k}}-\mathrm{y}_{\mathrm{k}}\right) \mathrm{f}^{\prime}\left(\mathrm{y} \mathrm{in}_{\mathrm{k}}\right)
$$

calculate the weight correction (which is used to correct the value $w_{j k}$ ):

$$
\Delta \mathrm{w}_{\mathrm{jk}}=\alpha \delta_{\mathrm{k}} \mathrm{z}_{\mathrm{j}}
$$

calculate the correction bias (whichis used later to correct the value $\left.\mathrm{w}_{0 \mathrm{k}}\right)$ :

$$
\Delta \mathrm{w}_{0 \mathrm{k}}=\alpha \delta_{\mathrm{k}}
$$

$\delta_{\mathrm{k}}$ sent to the unit that is in the lower layer.

e. Delta input is added by each hidden unit $\left(Z_{j}, j=\right.$ $1,2,3, \ldots ., p)$ from the units in the layer above it using:

$$
\delta_{-} i n_{j}=\sum_{k=1}^{m} \delta_{k} w_{j k}
$$

the derivative of the activation function is multiplied by this value with the error information calculated using:

$$
\delta_{\mathrm{j}}=\delta_{-} \mathrm{in}_{\mathrm{j}} \mathrm{f}^{\prime}\left(\mathrm{z} \mathrm{in}_{\mathrm{j}}\right)
$$

weight correction which will later be used to correct the value of Vij calculated using:

$$
\Delta \mathrm{v}_{\mathrm{jk}}=\alpha \delta_{\mathrm{j}} \mathrm{x}_{\mathrm{i}}
$$

weight correction which will later be used to correct the value of $\mathrm{V} 0 \mathrm{j}$ calculated using:

$$
\Delta \mathrm{v}_{0 \mathrm{j}}=\alpha \delta_{\mathrm{j}}
$$

f. Each unit of output $\left(\mathrm{Y}_{\mathrm{k}}, \mathrm{k}=1,2,3, \ldots \ldots, \mathrm{m}\right)$ weight and bias $(\mathrm{j}=0,1,2, \ldots \ldots, \mathrm{p})$ repaired using:

$$
w_{j k}(\text { new })=w_{j k}(\text { old })+\Delta w_{j k}
$$

Each hidden unit $\left(Z_{j}, j=1,2,3, \ldots \ldots, p\right)$ weigh and bias $(\mathrm{i}=0,1,2, \ldots, \mathrm{n})$ repaired using:

$$
\mathrm{v}_{\mathrm{ij}}(\text { new })=\mathrm{v}_{\mathrm{ij}}(\text { old })+\Delta \mathrm{v}_{\mathrm{ij}}
$$

(ii). The test conditions are stopped.

\subsection{Ant Colony Optimization \\ 2.5.1. Neural Network Selection}

First, select three layers of feedforward artificial Neural Networks, as shown in Figure 3[14],[15], [16]:

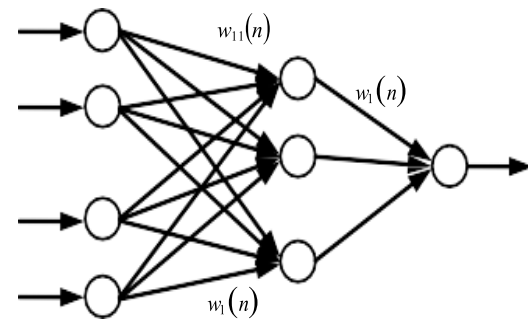

Figure 3. Layer of Neural Network

Input from Neural Network is $y(n-i)$ and output is $\bar{X}(n)$. The input of each neuron is $u$ and output is $v$, for example $u_{i}^{I} \quad$ represents the input signal from in neurons $i$ layer $I$. The weight of the connection between the input layer and the hidden layer is $w_{i j}(n)(i=$ $1,2,3, \ldots, I ; j=1,2,3, \ldots, J)$ and the connection weight between the hidden layer and the output layer is $w_{j}(n)$. Therefore, the equation of state from the three layers of the feedforward Neural Network is as follows:

$u_{i}^{I}(n)=y(n-i)$

$v_{i}^{I}(n)=u_{i}^{I}(n)=y(n-i)$

$u_{j}^{J}(n)=\sum_{i=1}^{I} w_{i j}(n) v_{i}^{I}(n)$

$$
=\sum_{i=1}^{I} w_{i j}(n) y(n-1)
$$

$V_{j}^{J}(n)=F_{1}\left(u_{j}^{J}(n)\right)=F_{1} \sum_{i=1}^{I} w_{i j}(n) y(n-1)(20)$

$u(n)=\sum_{j=1}^{J} w_{j}(n) v_{j}^{J}(n)$

$v(n)=\bar{X}(n)=f_{2}(u(n))$

$$
=f_{2}\left(\sum_{j=1}^{J} w_{j}(n) v_{j}^{J}(n)\right)
$$

Where, $f_{1}($.$) and f_{2}($.$) each refers to the transfer function$ of the hidden layer and the output layer.

\subsubsection{Initialize Neural Network weights to Ant Colony Optimization}

The idea of the Ant Colony Optimization algorithm that optimizes the initial weight of the Neural Network is that each ant looks for a group of weighted combinations in the 
weight solution space according to an updated pheromone matrix with average squared errors of Neural Network output, to help these ants meet the same route, that is, the same weighted combination, which functions as the initial weight of the Neural Network.

\subsubsection{Ant Colony Optimization Initialitation}

To generate individual $q$ values randomly in a range of weights $(-b, b)$ in a neural network. Each value will randomly generate an appropriate initial level and be stored in the pheromone matrix $\tau_{i j}$ as the initial pheromone density for each weight.

\subsubsection{The Selection of Heuristic Functions}

Blind equalization algorithm selects the weight value without the help of empirical value, therefore, there is no heuristic factor in the state transfer strategy, and the selection is conducted in random according to the probability of the pheromone density on route. According to prabability transfer formula, each ant chooses one from the $\mathrm{q}$ individual values to serve as the weight ij $\mathrm{w}$ from input layer to output layer, and the weight $\mathrm{j}$ w from hidden layer to output layer, which will be placed in Tabu as a weighted combination of Neural Network. The probability transfer formula is as follows in equation:

$$
P\left(\tau_{i j}\right)=\frac{\tau_{i j}}{\sum_{j=1}^{q} \tau_{i j}}(j=1,2,3, \ldots, J)
$$

\subsubsection{The Pheromone Updating}

The pheromone updating takes place after the selection of a weighted combination by each ant and the discovery of the optimal solution, and the pheromone matrix update is accroding to the formula:

$$
\tau_{i j}=\left\{\begin{array}{c}
(1-\rho) \tau_{i j}+\rho \Delta \tau_{i j}^{k}, \text { optimal w } \\
(1-\rho) \cdot \tau_{i j}, \text { others }
\end{array}\right.
$$

Where $(1-\rho)$ is the evaporation rate of pheromone, $\rho \in(0,1)$; and $\Delta \tau_{i f}^{(k)}$ is the changing rate of the pheromone of the weight value selected by the $k$, the value of which can be referred to as $\Delta \tau_{i f}^{(k)}=\mathrm{Q} / \mathrm{L}$, with $\mathrm{Q}$ as the coefficient and $\mathrm{L}$ as the error of this iterative optimal weighted combination.

\subsubsection{Repeated terminal conditions}

When using the Ant Colony Optimization to optimize the initial weight of the Neural Network, there are two terminal conditions, one is the number of cycles of the NC Ant Colony Optimization algorithm, the other is the error value is less than the specific value $\beta$. In this research, the two conditions above will help end the cycle.

\subsubsection{Ant Colony Optimization Algorithm with Neural Network}

The steps for implementing the Ant Colony Optimization algorithm with Artificial Neural Networks are as follows:

1. The ant group value in the initial ant is initialized with $\mathrm{M}$, and the weight value is initialized with Dim, while the initial pheromone matrix refers to $\tau_{i j}$ as the route each ant refers to a Neural Network. The repeat cycle coefficient is set to $\mathrm{NC}=1$.

2. Launch ant travel according to the probability transfer formula. Each ant forms a set of Neural Network weights after one search, which is stored in the Taboo list.

3. Bring the combination found by each ant into the Neural Network and calculate the error output E, and choose the weights $w_{i j}$ which has the smallest error.

4. Update pheromone matrix $\tau_{i j}$, and clear the Taboo list.

5. If the terminative conditions are met repeatedly, then the cycle will end, if not, will jump back to step 2 with the rule $\mathrm{NC}=\mathrm{NC}+1$.

When the results of the cycle meet one of the repetitive terminals, the system will stop the cycle automatically, and the optimal weight combination will function as the initial weight of the Neural Network, which will then be trained by the Back Propogation algorithm to find the optimal solution.

\section{Result and Analysis \\ 3.1. Signature Identification System Testing 3.1.1. Dataset}

The data used in this research are primary data consisting of a collection of images totaling 1000 data, consisting of 100 people / 10 signatures, each of 5 signature images for the training process (enrollment) and 5 signature images for the identification process. Query data and testing data are obtained from data retrieval directly. The data used has standard conditions such as image data that has been normalized, measuring $200 \times 200$ pixels, with a scale of 8 bits per channel (grayscale) and in the .bmp format.

\subsubsection{Testing Neural Network Methods}

Testing the Gabor Wavelet, Neural Network, and Ant Colony Optimization Transformation methods is done by counting the amount of test data that is correctly identified, that is data that indicates that the image is approaching the image reference. To get the overall accuracy value, a calculation of the value of all 100 people is obtained from the reference data (training data) and new data (testing data). The results of the accuracy value of the method used after each person's percentage:

a. Neural Network

- The number of correct or accepted signature images of the system is 77 ;

- The sum of all identified signature images is 100 ; 
While the accuracy generated from the whole data is as follows:

- The number of true or acceptable signature images of the system is 566 ;

- The total number of signature images used is 1000 ;

b. Neural Network and Ant Colony Optimization

- The results of the accuracy value of the method used after each person's percentage:

- The number of correct or accepted signature images of the system is 83 ;

- The sum of all identified signature images is 100;

While the accuracy generated from the whole data is as follows:

- The number of true or acceptable signature images of the system is 626 ;

- The total number of signature images used is 1000 ;

Formula for calculate the accuracy is:

Accuracy $=\frac{\text { the amount of correct data }}{\text { the amount all of data }} \times 100 \%$ (25)

Table 1. Accuracy Percentage for each people

\begin{tabular}{ll}
\hline Method & Accuracy \\
\hline Neural Network & $77 / 100=77 \%$ \\
Neural Network and Ant Colony Optimization & $83 / 100=83 \%$ \\
\hline
\end{tabular}

Table 2. Accuracy of The Whole Data

\begin{tabular}{ll}
\hline Method & Accuracy \\
\hline Neural Network & $566 / 1000=57 \%$ \\
Neural Network and Ant Colony Optimization & $626 / 1000=63 \%$ \\
\hline
\end{tabular}

\subsection{Discussion}

From Tables 1 and 2 , it is found that the results of identification from primary data testing individual signatures get different levels of accuracy obtained from each method, the percentage of individuals, namely for Neural Networks alone by $77 \%$ and Neural Networks with Ant Colony Optimization by $83 \%$. The results of identification of the overall primary signature data used get different levels of accuracy obtained from each method, with a percentage that is for Neural Networks only at $57 \%$ and Neural Networks with Ant Colony Optimization at $63 \%$.

The Ant Colony Optimization method which is used as an optimization to identify the signature image has a good performance and affects the accuracy of the test results, this is because the accuracy value after using Ant Colony Optimization has increased compared to before the optimization using Ant Colony Optimization or with Neural Network methods only.

In its application, the result of the identification of the signature image is also influenced by the parameter values used both on the Neural Network and Ant Colony Optimization such as learning rate, iteration, and so on.

The large number of data classifications used also affects the results of data identification, the signature image that has a number of classifications is less has greater accuracy than many data classifications, but if the number of classifications used is large, softmax can be used for great accuracy.

The results of the research also showed the successful recognition of the signature image due to the similarity to the results of the image recognition that was carried out, but there were a number of signature images that failed to be identified while looking the same, this was due to the many forms of style or variation of the signature as in the data testing does not have the existing image data in the database. If more variations of individual signature images are added to the database, it is expected that the accuracy of the signature identification can be improved.

\section{Conclusion}

The use of signatures as a basis for data validation has become a reference for proof of endorsement from someone in almost every aspect, including banking, industry, companies, government, etc. so that a signature identification system is needed. Signature identification systems have been developed, but have a small degree of accuracy. The signature identification system developed in this research uses the transformation of Gabor Wavelet, Neural Network, and Ant Colony Optimization resulting in an accuracy of $83 \%$, where the accuracy before the optimization is $77 \%$. Meanwhile, the accuracy of using primary data as a whole is $57 \%$ using Neural Networks only, and 63\% using Neural Networks and Ant Colony Optimization. These results show an increase in the accuracy of the Neural Network method after being optimized using Ant Colony Optimization, with this increase expected to help identify someone's signature ownership more accurately so that it can be used for further decision making.

\section{Reference}

[1]. Frias-Martinez, E., Sanchez, A., \& Velez, J. Support vector machines versus multi-layer perceptrons for efficient off-line signature recognition. Engineering Applications of Artificial Intelligence, vol. 19 no. 6, pp. 693-704. 2006

[2]. Vincent Kusuma dan Darmaji. Elliptic Curve dan Implementasinya pada Algoritma Tanda Tangan Digital. Jurnal Sains dan Seni Pomits. Vol. 3, No. 2, Page. 1-2. 2014.

[3]. Zaitun, Warsito, Gurum Ahmad Pauzi. Sistem Identifikasi dan Pengenalan Pola Citra Tanda-Tangan Menggunakan Sistem Jaringan Saraf Tiruan Dengan Metode Backpropagation. In Jurnal Teori dan Aplikasi Fisika. Vol. 03, No. 02. Page. 1-4. 2015.

[4]. Romi Wiryadinata, Raya Sagita, Siswo Wardoyo, Priswanto. Face Recognition in the Presence System Using the Dynamic Times Wrapping Method, Principal Component Analysis and Gabor Wavelet. In Dinamika Rekayasa. Vol. 12 No. 1. Page. 2-3. 2016 
[5]. Paulus Bangun Martu, Komarudin, Armand Omar Moeis, Akhmad Hidayatno. Perancangan Algoritma Ant Colony Optimization Untuk Penyelesaian Vehicle Routing Problem. Prosiding Seminar Nasional dan Workshop Pemodelan dan Perancangan Sistem. Page. 2-4. 2011.

[6]. Michalis Mavrovouniotis, Shengxiang Yang. Training Neural Networks with Ant Colony Optimization algorithms for pattern classification. Centre for Computational Intelligence (CCI). Page. 1-6. 2013.

[7]. Travis Desell, Sophine Clachar, James Higgins, and Brandon Wild. Evolving Deep Recurrent Neural Networks Using Ant Colony Optimization. In The 15th European Conference on Evolutionary Computation in Combinatorial Optimization. 2015.

[8]. Michalis Mavrovouniotis, Shengxiang Yang. Training Neural Networks with Ant Colony Optimization algorithms for pattern classification. Soft Computing, vol. 19 no. 6, pp. 1511-1522, 2015.

[9]. I Made Dwi Udayana Putra, G. K. Gandhiadi, Luh Putu Ida Harini. Implementation of Backpropagation Neural Network in Weather Forecast in South Bali. In E-Jurnal Matematika. Vol. 5 (4). Page. 2-5. 2016.

[10]. Shima Kashef, Hossein Nezamabadi-pour. A new feature selection algorithm based on binary Ant Colony Optimization. The 5th Conference on Information and Knowledge Technology. In iranian association of information and communication technology. Page. 1-3. 2013.
[11]. Ignasius Donny Fernando, Heri Prasetyo, Esti Suryani. Symmetrical Singular Value Decomposition Representation Under Illumination Face Image Using Gabor Filter For Face Recognition. In Jurnal Ilmiah Teknologi dan Informasi . Vol. 6, No. 2. Page. 2-4. 2017.

[12]. Mutmainnah Muchtar dan Laili Cahyani. Klasifikasi Citra Daun dengan Metode Gabor Co-Occurence. In ULTIMA Computing. Vol. VII, No. 2. Page. 2-6. 2015.

[13]. Candra Dewi, M. Muslikh. Perbandingan Akurasi Backpropagation Neural Network dan ANFIS Untuk Memprediksi Cuaca. In Journal of Scientific Modeling \& Computation. Volume 1 No.1. Page. 2-4. 2013.

[14]. Andri Zarman, Mohamad Irfan, Wisnu Uriawan. Implementasi Algoritma Ant Colony Optimization Pada Aplikasi Lokasi Tempat Ibadah Terdekat Dikota Bandung. In JOIN . Volume I No. 1. Page. 3-5. 2016.

[15]. Qiang Liu, Guoqiang Huang, Chen Mao, Yu Shang, Fan Wang. Recognition of Dissolved Gas in Transformer Oil by Ant Colony Optimization Support Vector Machine. IEEE. Page. 1-2. 2016.

[16]. Yanxiang Geng, Liyi Zhang, Yunshan Sun, Yao Zhang, Nan Yang and Jiawei Wu. Research on Ant Colony Algorithm Optimization Neural Network Weights Blind Equalization Algorithm. In International Journal of Security and Its Applications. Vol. 10, No. 2. Page 2-5. 2016. 